\title{
Determinants of Demand for Credit: A Conceptual Review
}

\author{
Yusuf Ibrahim Kofarmata ${ }^{1}$ \\ Shri Dewi Applanaidu ${ }^{2}$ \\ Sallahuddin Hassan ${ }^{3}$
}

${ }^{1}$ Department of Economics and Agribusiness, Universiti Utara, Malaysia; Lecturer, Department of Economics, Northwest University, Kano-Nigeria

${ }^{2}$ Department of Economics and Agribusiness, Universiti Utara, Malaysia

Department of Economics and Agribusiness, Universiti Utara, Malaysia

( Corresponding Author)

\begin{abstract}
It is generally agreed among the researchers that farm credit has significant positive impact on agricultural production that would increase the farming output. In fact, the rising cereal production were more related to farm inputs that may be acquired through agricultural credit. In view of that, this article synthesizes and reviews different field studies on the determinants of demand for credit. Moreover, it is clear from the reviewed studies that different models have been used in examining the factors that determine the demand for credit. However, most of the findings are inconclusive, due to the contextual, geographical, socio-economic, environmental and other variations across the study areas. Based on that, the paper call the need for more empirical studies on the determinants of demand for credit for a specific region for better policy that may be suitable for that particular region. This has important implications on agricultural production in general and farm credit in particular, especially for developing economies.
\end{abstract}

Keywords: Agricultural production, Credit, Determinants, Demand, Farming.

\section{Contents}

1. Introduction

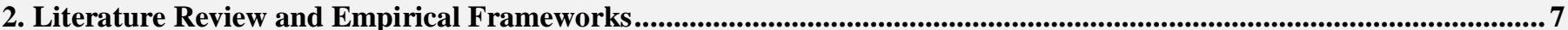

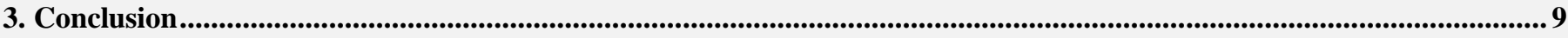

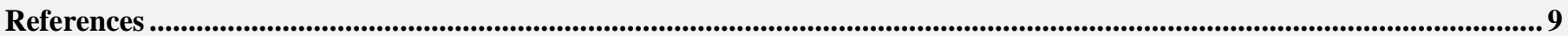

Citation | Yusuf Ibrahim Kofarmata; Shri Dewi Applanaidu; Sallahuddin Hassan (2016). Determinants of Demand for Credit: A Conceptual Review. Asian Journal of Economics and Empirical Research, 3(1): 6-10.

DOI:

ISSN (E):

ISSN (P):

10.20448/journal.501/2016.3.1/501.1.6.10 Crossref

Licensed:

$2409-2622$

2518-010X Contribution/Acknowledgement: All authors contributed to the conception and design of the study
Funding:

Funding:

政

Competing Interests:

Transparency:

The authors declare that they have no conflict of interests.

The authors confirm that the manuscript is an honest, accurate, and transparent account of the study was reported; that no vital features of the study have been omitted; and that any discrepancies from the study as planned have been explained

Ethical:

This study follows all ethical practices during writing.

Ethical:

Publisher:

Received: 28 November 2015/ Revised: 13 December 2015/ Accepted: 17 December 2015/ Published: 21 December 2015 Asian Online Journal Publishing Group 


\section{Introduction}

The significance of credit as one of the tools of production that has been found to spurs economic growth and sustainable development in rural areas could not be over emphasized. However, According to Tang et al. (2010) due to the high degree of risks in particular and economic uncertainties associated with rural life in general, risk mitigating components such as insurance were missing or completely absent. Even though, rural dwellers do help themselves in the unfortunate events, however, previous studies persistently were unable to prove that rural dwellers are able to insured each other (Townsend, 1994). Besides, lack of insurance facility couple with limited savings have placed small-scale rural households vulnerable to idiosyncratic shocks and several risks (Tang et al., 2010). Consequently, credit access is crucial on agricultural investment, production and consumption and more importantly rural life (Eswaran and Kotwal, 1990; Udry, 1990).

Agricultural credit supports rural communities in a number of ways. Access to farm credit increase the capability of rural farmer with limited savings to meet his financial demand for productive investments and farm inputs. Moreover, farm credit encourage rural farmers to accommodate new farming techniques by increasing their capability to engage in more productive business but more risky (Carter, 1984; Rosenzweig and Binswanger, 1993). Similarly, greater credit access helps rural farmers to supplement their consumption during the economic downturn. Besides, empirical studies has emphasized the significance of rural credit in rural economies. In China, Feder et al. (1990) found that an extra Yuan of credit will return 0.24 Yuan of extra value of farm output. Similar result was reported in Malawi where Diagne et al. (2000) confirmed that access to credit has positive significant impact on farmers' welfare. While, using Peruvian data, Guirkinger and Boucher (2008) shows that on average credit constraints farmers losses about 27 percent of their agricultural output.

\section{Literature Review and Empirical Frameworks \\ 2.1. Formal and Informal Credit Markets}

One very common attributes of credit markets in rural areas of the developing economies is the existence of informal and formal credit markets (Hoff and Stiglitz, 1990; Besley, 1995; Bell et al., 1997; Kochar, 1997; Barslund and Tarp, 2008; Guirkinger and Boucher, 2008). Two different arguments have been forward as the reasons of their co-existence. The first one explained that the existence of informal credit market was as the result of the stringent governments' policies on the formal market sector (Bell et al., 1997; Kochar, 1997). Most governments of developing economies have imposed some policies on the formal sector such as interest rate ceiling in order to strengthen the formal lending and discourage informal market which charge higher interest rate on one hand. But, interest rates ceilings on the other hand, has negative effect on loanable fund. It can also possibly stagnate the supply of credit from formal markets to the poor households. Since this type of households are usually at risks, where at below the ceiling price, lending to poor households may not yields more return. In this aspects, a number of researchers such as Bell (1990) and Hoff and Stiglitz (1990) envisages that government polices largely failed to yields desired results. Due to the ceilings of interest rates in the formal markets, the informal credit markets has continue to dominate the transaction in the rural markets, with higher interest rate in many cases. This has raise some doubt in the reliability and the rationale behind the regulations in the formal sectors (Hoff and Stiglitz, 1990).

Another argument with respect to the formal and informal credit markets is associated with rationing in the credit market due to the information asymmetric between the borrower and lender. Since asymmetric of information is prevalent in the credit markets, formal lender is only keen to release money to borrower with tangible assets on one hand. On the other hand, informal lender can release money to borrower even without physical assets that can be placed in the form of collaterals.

Informal lenders can able to take such risks, because they have informational advantage over the formal counterpart about borrowers habits and their productive capacities, so that they can employ different mechanisms to re-enforce repayment (Zeller, 1994; Bardhan and Udry, 1999). Though both the two arguments explained more on the factors affecting credit supply, while demand-side factors were skewed in the analysis. As a result, several studies have argued that the analysis of rationing in the formal financial sector has been overestimated (Kochar, 1997). In this regards, many factors have been acknowledged in the literature as the factors that determine the overall rural households' demand for loan. Tang et al. (2010) identified savings and liquid assets as a significant factors that influence the overall demand for credit. Idiosyncratic and Covariate shocks were also another factor. High costs of transaction including bureaucratic loan process, tedious paper work related with formal credit, collateral risk and high interest rates (Foltz, 2004; Guirkinger and Boucher, 2008). Availability of formal credit market, political reasons and asymmetric information have all been recognized as the key factors that influence the demand for loan (Zander, 1994).

\subsection{Factors Affecting the Demand for Credit}

In the study conducted in Uganda, Mpuga (2010) found that age of the farmer is positively related to demand for credit and the quantity of loan applied. According to him, the young are likely to borrow, since they are very active and energetic and more aggressive to investment. While, old individuals are likely to rely more on the past earnings and accumulated capital, and therefore less inclined to need loan. Even though contrary to Mpuga, Tang et al. (2010) found that old households are more probable to demand credit than the younger ones. Because these type of households have higher social capital and social network that may likely increase their credit access.

While, in a different study household's age has no significant effect on credit demand (Nwaru, 2011).Asset acquisition by women is hindered by social restriction especially in developing countries. Whereas, in rural communities there is segregation of gender activities. Those among the women who engaged in productive and more independent economic activities will be traditionally seen as deviated from social norms. However, if this tradition is strong enough, women in this community may not demand any credit, even if they have gainful investment 
(Fletschner and Carter, 2008). Consequently, the likelihood to demand for credit in the formal market is decreasing with being female headed-household (Bendig et al., 2009; Nwaru, 2011).

In a different study in Ghana, using multinomial probit regression (Bendig et al., 2009) shows that household size is positively related to demand for microcredit. This is because households with more members are likely to spend more in consumption and education, thus, they are likely to demand loan. While in a survey study in China, Tang et al. (2010) indicated that education is one of the significant explanatory variables that influence the demand for loan. They also found that an additional year of schooling by household-head will raise the likelihood of borrowing by $2.5 \%$. Similarly, the probability to demand for loan will increase by $5.6 \%$ if the land endowment double. Although, the influence of these factors varies considerably according to type of credit markets. For instance, while years of schooling increases households borrowing chances from formal financial institutions, it however reduces or have no effect with regard to the informal credit market. Nonetheless, this does not always holds, as Chen and Chiivakul (2008) found that those with moderate education (primary and secondary level) are likely to demand for loan, but it has no impact with respect to tertiary education.

This implies that highly educated households have already acquired wealth, and therefore have little credit demand. Moreover, Bendig et al. (2009) established that more educated households are likely to demand formal credit, and credit demand was considerably affected by transaction costs. This has been confirmed by many studies (Zeller et al., 1998). For example, an extra kilo meters between the nearest bank and village reduces the borrowing probability from the formal lenders by $1 \%$ (Tang et al., 2010). In contrast, Mpuga (2004) has not established any significance evidence between village distance and demand for loan. Chen and Chiivakul (2008) argued that household may demand credit, while his current income is high due to the expectations of future income, which will guarantee his repayment. Similarly, it may be possible that if the household level of income goes down, his consumption marginal utility will be high which may led to higher credit demand. Additionally, households are expected to borrow once he possessed some tangible assets which can be placed as collateral.

Along this line, Magri (2002) maintained that total wealth that represents current and future household's endowment, is one of the significant factors of demand for credit. While, with growing endowment a household can expand his productive capacity and take care for his consumption variability, hence his credit demand will become very low. However, at some level of wealth, an increase in household's endowment may probably raise the consumption needs, hence will upsurge the willingness for a household to demand for credit. Following this, Chen and Chiivakul found that total assets have positive and significant impact on the demand for loan. But at higher level, an increase in wealth will significantly reduce the demand for loan.

Moreover, using household data from Madagascar, Zeller (1994) examined the demand factors for credit and credit rationing in the formal and informal credit markets. He found that being laborer, number of sick days, having social responsibility and being the head of the family are positively associated with borrowing. Similarly, household's occupation, level of education, land endowments and family size are very important determinants of credit constraints status of the farmers.

Household's asset is a significant element that individual take in to account when it comes to borrowing decision. In this regards, Duflo et al. (2008) shows that number of livestock owned has a decreasing effect on household's demand for credit. However, Mpuga (2010) contends that it is not the total amount of assets accumulated, rather total value of assets such as land and building owned by the household that have strong positive effect on the demand for loan. Furthermore, Bendig et al. (2009) concludes that wealth endowment and being employed in the administration encourage the use of financial service.

However, individual who is receiving remittances do not exhibit demand for micro loan. This confirmed the general assumption that very poor households are less likely to be included in the formal credit market than wealthier households (Mohieldin and Wright, 2000; Nguyen, 2007). The finding also specified that borrowers were characterized by greater assets and high earnings that could be served as collateral. Households may need loan for investments decision, or to smooth consumption. In this way, households who experiences shocks are more likely to demand loan than those who demand credit for other purposes. Events that were found to affect the demand for credit are bad harvest and social events such as marriage and other festivities. Though the effect of these factors varies across different sources of credit. For example, being salary earner and distance from the village to the nearest banks have positive impact with respect to informal credit demand (Nwaru, 2011). Similarly, results from India shows that households' entrepreneurial skills, occupation and off-farm investments are positively related to institutional borrowing (Kumar et al., 2010). However, the amount of money a household may demand within the considerable time and his investment decision depend on his school years, farm size, household's age, distance, socio-economic interaction and household size, Ewuola and Williams (1995). Even though, by considering the profitability of investments and price of loan as one of the investment and borrowing conditions; a household may borrow capital if the expected project return is higher than the cost of borrowing (Sylvanus, 2003).

In a different study in Ghana, Koomson et al. (2014) indicates that the probability of being discouraged from credit applications increases with low savings and low income earnings. While, in a study conducted in Vietnam, Thanh et al. (2015) found that having owned residential area, per capita land area, education are the key determinants of access to credit. While, average years of schooling has significant impacts on the likelihood of acquiring higher amount of loan. Their studies have yields an interesting finding that being native poor and percentage of off-farm income have positive effects with respect to formal borrowing. Similarly, interest rate has statistical relevance on the loan amount demanded. In summary, these inconsistencies and inconclusive findings may be due to the regional variations with respect to weather, infrastructure, credit availability and government policies, while socio-economic attributes plays a vital roles in response to credit demand. This indicates that findings from one region may not be generalized to another region. 


\section{Conclusion}

This article reviews the various field studies on the factors that influence the demand for credit by farmers. Perhaps, empirical studies that have been reviews in this paper, methodologically can be categorized into three different groups, though not explicitly demonstrated in the review process.

The first category are those that used categorical models as a tools of data analysis in order to investigate the factors that determine the demand for credit. These includes (Zeller, 1994); Guirkinger and Boucher (2008); Barslund and Tarp (2008) among the others. The second group consists of those studies that analyses the determinants of demand for loan using ordinary least square and other truncated models such as Nwaru (2011) and Thanh et al. (2015). While, the third groups comprises of those that combined different methods in order to satisfy their conflicted objectives, such as Mpuga (2010; 2004). Additionally, it was demonstrated in this paper that various empirical studies used a number of different variables that depends largely on the researcher's a priori expectations.

Though, in many cases, the variables do overlap in different studies, which result in different conclusions and inconsistent findings. This generally stems from the contextual and geographical variations across the case study areas. It may also arises due to the fact the socio-economic conditions of households given a particular region varies with other factors such as the quality of soil, climate conditions, cultural practices, and the characteristics of financial markets. Therefore, more studies are needed with respects to credit market participation, the amount of loan and the choice of credit market especially in a specific regions of the developing countries. So that the findings of these studies will augment some policies that actually reflect the needs of those particular communities for rural sustainable development in general and agriculture in particular.

\section{References}

Bardhan, P. and C. Udry, 1999. Development microeconomics. New York: Oxford University Press.

Barslund, M. and F. Tarp, 2008. Formal and informal rural credit in four provinces of Vietnam. Journal of Development Studies, 44(4): 485503.

Bell, C., 1990. Interactions between institutional and informal credit agencies in rural India. World Bank Econ. Rev, 4(3): $297-327$.

Bell, C., T.N. Srinivasan and C. Udry, 1997. Rationing, spillover, and interlinking in credit markets: The case of rural Punjab. Oxford Economic Papers, 49(4): 557-585.

Bendig, M., L. Giesbert and S. Steiner, 2009. Savings, credit and insurance: Household demand for formal financial services in rural Ghana. Working Paper No. 94, German Institute of Global and Area Studies.

Besley, T., 1995. Nonmarket institutions for credit and risk sharing in low-income countries. Journal of Economic Perspectives, 9(3): 115-127.

Carter, M.R., 1984. Identification of the inverse relationship between farm size and productivity: An empir- ical analysis of peasant agricultural production. Oxford Economic Papers, 36(1): 131-145.

Chen, K.C. and M. Chiivakul, 2008. What drives household borrowing and credit constraints? Evidence from Bosnia and Herzegovina. New York. IMF Working Papers, 08(202): 1-31.

Diagne, A., M. Zeller and M. Sharma, 2000. Empirical measurements of households access to credit and credit constraints in developing countries: Methodological issues and evidence. Working Paper, No. 90.

Duflo, E., B. Crepon, W. Pariente and F. Devoto, 2008. Poverty, access to credit and the determinants of participation in a new microcredit programme in rural areas of Morocco. Impact Analyses Series, No. 02: 1-40.

Eswaran, M. and A. Kotwal, 1990. Implications of credit constraints for risk behaviour in less developed economies. Oxford Economic Papers, 42(2): 473-482.

Ewuola, S.O. and S.K. Williams, 1995. Effects of institutional and borrowers' characteristics on loan recovery: A study of Ondo State agricultural credit corpoartion. Journal of Agriculture, Food and Development, 1(2): 104-113.

Feder, G., L.J. Lau, J.Y. Lin and X. Luo, 1990. The relationship between credit and productivity in Chinese agriculture: A microeconomic model of disequilibrium. American Journal of Agricultural Economics, 72(5): 1151-1157.

Fletschner, D. and M.R. Carter, 2008. Constructing and reconstructing gender: Reference group effects and women's demand for entrepreneurial capital. Journal of Socio-Economics, 37(2): 672-693.

Foltz, J.D., 2004. Credit market access and profitability in Tunisian agriculture. Agricultural Economics, 30(3): $229-240$.

Guirkinger, C. and S.R. Boucher, 2008. Credit constraints and productivity in Peruvian agriculture. Agricultural Economics, 39(3): 295-308.

Hoff, K. and J.E. Stiglitz, 1990. Imperfect and rural information credit markets-puzzles and policy perspectives. World Bank Economic Review, 4(3): 235-250.

Kochar, A., 1997. An empirical investigation of rationing constraints in rural credit markets in India. Journal of Development Economics, 53(2): 339-371.

Koomson, I., S.K. Annim and J.A. Peprah, 2014. Loan refusal, household income and savings in Ghana. Munich Personal RePEc Archive, No. 58049: 1-20.

Kumar, A., K. Singh and S. Sinha, 2010. Institutional credit to agriculture sector in India: Status, performance and determinants. Agricultural Economics Research Review, 23(2): 253-264.

Magri, S., 2002. Italian households' debt: Determinants of demand and supply. Banca d'Italia, No. 454, 454: 1-53.

Mohieldin, M.S. and P.W. Wright, 2000. Formal and informal credit markets in Egypt. Economic Development and Cultural Change, 48(3): 657-670.

Mpuga, P., 2004. Demand for credit in rural Uganda: Who cares for the peasants? A Paper Presented at the Conference on Growth, Poverty Reduction and Human Development in Africa Centre for the Study of African Economies. pp: 1-42.

Mpuga, P., 2010. Constraints in Access to and demand for rural credit: Evidence from Uganda. African Development Review, 22(1): 115-148.

Mpuga, P., 2010; 2004. Demand for credit in rural Uganda: Who cares for the peasants? A Paper Presented at the Conference on Growth, Poverty Reduction and Human Development in Africa Centre for the Study of African Economies. pp: 1-42.

Nguyen, C.H., 2007. Determinants of credit participation and its impact on household consumption: Evidence from rural Vietnam. Center for Economic Reform and Transformation, No. 03: 1-19.

Nwaru, J.C., 2011. Determinants of informal credit demand and supply among food crop farmers in Akwa Ibom State, Nigeria. Journal of Rural and Community Development, 6(1): 129-139.

Rosenzweig, M.R. and H.R. Binswanger, 1993. Wealth, weather risk and the composition and profitability of agricultural investments. The Economic Journal, 103(416): 56-78.

Sylvanus, I., 2003. Was there a credit crunch in Namibia between 1996 - 2000? Journal of Applied Economic, 6(2): 269-290.

Tang, S., Z. Guan and S. Jin, 2010. Formal and informal credit markets and rural credit demand in China. In Agricultural \& Applied Economics Association,CAES, \& WAEA Joint Annual Meeting. pp: 1-26.

Thanh, T.T.T., N.Q. Viet and H.H. Loi, 2015. Determinant of access to rural credit and its effect on living standard: Case study about poor households in Northwest, Vietnam. International Journal of Financial Research, 6(2): 218-230.

Townsend, R., 1994. Risk and insurance in village India. Econometrica, 62(3): 539-591.

Udry, C., 1990. Credit markets in Northern Nigeria: Credit as insurance in a rural economy. World Bank Economic Review, 4(3): 251-269.

Zander, R., 1994. Barriers to credit access in rural Sri Lanka. Financial landscapes reconstructed. The fine art of mapping development, Boulder, Colorado: Westview, Press. pp: 121- 128. 
Zeller, M., 1994. Determinants of credit rationing: A study of informal lenders and formal credit groups in Madagascar. World Development, 22(12): 1895-1907.

Zeller, M., A. Diagne and C. Mataya, 1998. Market access by smallholder farmers in Malawi: Implications for technology adoption, agricultural productivity and crop income. Agricultural Economics, 19(1): 219-229. 